\title{
A renin-angiotenzin-aldoszteron rendszer szerepe diabeteshez társuló depresszióban
}

\author{
Lénárt Lilla dr., ${ }^{(1,2)}$ Lakat Tamás, $^{(1,2)}$ Hodrea Judit dr., ${ }^{(1,2)}$ Fekete Andrea dr. ${ }^{(1,2)}$
}

\begin{abstract}
Összefoglalás
A diabetes mellitushoz (DM) gyakran társul depresszió, ami rontja az életminöséget és csökkenti a várható élettartamot. Igazolták, hogy a kapcsolat bidirekcionális, vagyis mind a depresszió, mind a cukorbetegség elöidézheti a másik betegség létrejöttét. A két betegség együttes elöfordulásának hátterében közös neurobiológiai, immunológiai és endokrinológiai eltérések figyelhetök meg. Feltételezhetö, hogy a depresszió kialakulásának egyik legfontosabb oka az agyi neurotrofikus faktor (BDNF) alacsony szintje, amihez a gyulladásos folyamatok jelentös mértékben hozzájárulnak. Nemrégiben vált ismertté, hogy az agyban müködik egy lokális renin-angiotenzin-aldoszteron rendszer (RAAS), amelynek hiperaktivitása gyulladásos folyamatokat indukál, és elösegiti a kognitiv zavarok és a depresszió kialakulását. Klinikai vizsgálatok alapján felvetödött, hogy a szisztémás RAAS gátlása összefügghet a depressziós tünetek enyhülésével. Kutatási eredmények igazolták, hogy a RAAS-inhibitorok csökkentik a gyulladást és fokozzák a neurotrofinok expresszióját, ezáltal neuroprotektiv szereppel rendelkeznek, ami felveti e szerek jótékony, antidepressziv tulajdonságát. Mindezek alapján valószinüsithetö, hogy a RAAS-gátlók segitségével a DM következtében kialakuló hypertonia és veseszövődmények mellett a hangulatzavarok is sikerrel kezelhetök.
\end{abstract}

Kulcsszavak: diabetes mellitus, depresszió, BDNF, RAAS-gátlók, gyulladás

\section{The role of renin-angiotensin-aldosterone system in diabetes associated depression}

Summary: Comorbid depression commonly occurs with diabetes mellitus (DM), which worsens quality of life and decreases life expectancy. Several lines of evidence suggest a bidirectional relationship between diabetes and depression, both disease may induce the development of the other. Common immunological processes, similar reaction to oxidative stress as well as common endocrinological and neurobiological factors are suspected to be involved. Decreased brain-derived neurotrophic factor (BDNF) level - which is resulted by inflammatory processes as well - is contributed to the development of depression. It has recently been proven that, a local renin-angiotensin aldosterone system (RAAS) expressing all classical signaling pathways also exists in the brain. Hyperactivity of brain RAAS contributes to the cognitive decline and the development of depression via induction of inflammatory responses. Furthermore, based on clinical observations, inhibition of RAAS may be related to the mitigation of the symptoms of depression. Studies indicate the neuroprotective effect of RAAS blockers via reducing inflammation and enhancing the expression of neurotrophins. These neuroprotective action of RAAS inhibitors may explain its antidepressive effect. Based on these findings RAAS inhibitors are potential agents for treating mood disorders besides hypertension and renal complications in diabetes.

Keywords: diabetes mellitus, depression, BDNF, RAAS-inhibitors, inflammation

Rövidítések

ACE: angiotenzinkonvertáló enzim (angiotensin-convertase enzyme); Ang Il: angiotenzin II; ARB: angiotenzinreceptor-blokkoló; AT: angiotenzinreceptor; BDNF: agyi neurotrofikus faktor (brain derived neurotrophic factor); ER: endoplazmatikus retikulum; ERK: extracelluláris szignál-mediált kináz (extracellular signal-regulated kinase); JNK: c-Jun N-terminális kináz; MAO: monoamin-oxidáz; MR: mineralokortikoid-receptor; NF-KB: nukleáris faktor kappa-B; 
p75Ntr: neurotrofinreceptor p75; PI3K: foszfoizonitid-3 kináz; PLC: foszfolipáz C; RAAS: renin-angiotenzin-aldoszteron rendszer (renin-angiotensin-aldosterone system); SSRI: szelektív szerotoninvisszavétel-gátló (selective serotonine reuptake inhibitor); TrkB: tropomiozinreceptor kináz B

\section{A cukorbetegség és a depresszió közötti kapcsolat}

A cukorbetegség és a depresszió közötti összefüggést Thomas Willis már a 17. században felismerte. Megállapította, hogy gyakrabban fordul elő cukorbetegség azoknál, akiket életük során komoly stressz vagy szomorúság ért. ${ }^{1}$ Ennek ellenére a felismerést követő 300 évben nem foglalkoztak tovább az összefüggés vizsgálatával. Napjaink kutatási eredményei szerint a két betegség kialakulása között szoros korreláció áll fenn, a depresszió mintegy 60\%-kal növeli a diabetes mellitus (DM) kialakulásának rizikóját, azaz több mint kétszer gyakrabban vezet cukorbetegség kialakulásához, mint bármilyen más pszichiátriai kórkép. ${ }^{2} \mathrm{Az}$ ezredforduló környékén végzett metaanalízisek révén ma már tudjuk, hogy az összefüggés fordítva is igaz: a depresszió prevalenciája és a depreszsziós tünetek gyakorisága kétszer magasabb cukorbetegekben, mint az egészséges populációban. Külön vizsgálva a nemeket azt is kimutatták, hogy nőkben még gyakoribb a cukorbetegséghez társuló depresszió kialakulásának valószínűsége. ${ }^{3}$ A két betegség együttes előfordulása esetén a cukorbetegség nehezebben kontrollálható, rosszabb a szénhidrát-anyagcsere, nő a diabeteses szövődmények száma és fokozódik a szuicid események rizikója. ${ }^{4}$

A DM és a depresszió együttes megjelenésében vitathatatlan a környezeti faktorok és az életmód szerepe is, hiszen a depressziós betegek sok esetben egészségtelenebbül élnek (többet dohányoznak, helytelenül táplálkoznak, fizikai aktivitásuk csökken); ami egyértelműen fokozza a DM kialakulásának kockázatát. ${ }^{5}$ A legújabb kutatások szerint azonban a komorbiditás hátterében nem csupán erről van szó.

A napjainkban végzett vizsgálatok molekuláris szinten próbálnak tisztább képet adni a két betegség kapcsoltsági viszonyáról, miszerint közös immunológiai folyamatok, az oxidatív stresszre adott hasonló válaszok, valamint közös endokrinológiai, neurobiológiai tényezők és agyi strukturális elváltozások állhatnak a háttérben. ${ }^{6}$
Immunológiai tényezök szerepe

a cukorbetegség és depresszió

kialakulásában

A DM és a depresszió patofiziológiájának vizsgálatakor számos gyulladással kapcsolatos mediátort azonosítottak. 1-es típusú DM (T1DM) során igazolták, hogy a béta-sejtek elhalásával párhuzamosan nő egyes inflammatorikus citokinek, az interleukin (IL)-1, az IL-6 és a tumor nekrózis faktor-alfa (TNF- $\alpha$ ) szisztémás szintje. ${ }^{7}$ Ugyanakkor az is ismert, hogy az emelkedett vércukorszint önmagában is serkenti a citokintermelést és roszszul kontrollált DM-es betegekben több az IL-4, IL-6 és TNF- $\alpha$ mennyisége a plazmában. ${ }^{8} 2$-es típusú DM-ben (T2DM) gyakori az obezitás, amelynek során a hipertrofizált zsírszövetben a nukleáris faktor kappa-B (NF-xB) és a c-Jun N-terminális kináz (JNK) szignalizációs útvonalak szintén gyulladást generálnak. Emellett a megnövekedett visceralis zsírszövetben fokozódik a proinflammatorikus hatású adipokinek termelődése is, amelyek elősegítik az inzulinrezisztencia kialakulását. ${ }^{9}$

Hasonló folyamatokat látunk depresszióban is: nő az IL-1, IL-6, TNF- $\alpha$ gyulladási mediátorok termelődése. ${ }^{10}$ A proinflammatorikus citokinek bejutva a központi idegrendszerbe csökkentik a monoaminok szintjét és depresszióhoz hasonló tüneteket (kimerültség, étvágytalanság, alvászavar) idéznek elő. ${ }^{11}$ A depresszió következtében létrejövő szisztémás szubklinikus gyulladás hozzájárul a béta-sejtek csökkent működéséhez és ezáltal az inzulinrezisztencia, illetve a T2DM létrejöttéhez. ${ }^{12}$

\section{Az agyi neurotrofikus faktor szerepe a komorbiditiás kialakulásában}

A DM és a depresszió közös vonásait tekintve meglepően hasonló idegrendszeri eltéréseket figyelhetünk meg. Képalkotó eljárásokkal mindkét betegségben kimutatható a hippocampus és az agykéreg atrófiája, valamint a cerebrális glukózmetabolizmus csökkenése. ${ }^{13}$ A megfigyelt jellegzetes 
strukturális elváltozások alapján felmerült a neurotrofinok, főként az agyi neurotrofikus faktor (BDNF) molekuláris szerepe a komorbiditás kialakulásának hátterében. ${ }^{6}$

A BDNF a neurotrofinok családjába tartozó fehérje, amely főként a központi és perifériás idegrendszerben termelődik, azonban nem neurogén szövetekben is kimutatható. A neurotrofinok egy fehérjecsalád, amely az idegsejtek túlélését, differenciációját és funkcióját szabályozza. Négy fő fehérje tartozik a családba: BDNF, idegi növekedési faktor, neurotrofin-3 és a neurotrofin-4. Mint az összes neurotrofin, a BDNF is először prekurzor formában szintetizálódik az endoplazmatikus retikulumban (ER), amelyből az érett forma proteolitikus hasítás révén alakul ki. A prekurzorból az érett forma átalakulása történhet intracellulárisan - furin és fehérjekonvertázok révén -, valamint extracellulárisan, plazmin és mátrix metalloproteinázok segítségével. ${ }^{14} \mathrm{~A}$ keletkezett érett forma kötődik és ezáltal aktiválja a tropomiozinreceptor kináz B-t (TrkB). A receptor aktiválódása foszforilációs kaszkádot indít el, ami során aktiválódnak az extracelluláris szignál-mediált kináz (ERK), a foszfoizonitid 3-kináz (PI3K) és a foszfolipáz C (PLC) útvonalak. Ezek a szignáltranszdukciós mechanizmusok hozzájárulnak az axonok és dendritek növekedéséhez, a neurotranszmitterek szintéziséhez és felszabadulásához, valamint a pre- és posztszinaptikus sejtek aktiválódási hatékonyságának növeléséhez. ${ }^{15}$

Korábban úgy gondolták, hogy az extracelluláris térbe kijutó prekurzor forma inaktív, biológiai folyamatokat nem modulál. Lee és munkatársai azonban kimutatták, hogy a prekurzor BDNF a neurotrofinreceptor p75 (p75Ntr) aktiválásával beindítja az NF- $x \mathrm{~B}$ és JNK szignáltranszdukciós útvonalat, és ezáltal főként apoptózist, valamint csökkent szinaptikus hatékonyságot idéz elő. ${ }^{16} \mathrm{Ez}$ a hatás ellentétes az érett BDNF-TrkB által aktivált szignalizációs mechanizmusokkal.

Klinikai és állatkísérletek egyaránt megerősítették a BDNF központi szerepét a neuropszichiátriai betegségek kialakulásában. ${ }^{17} \mathrm{~A}$ hippocampusban és a prefrontális régióban lokalizálódó neuronokra élettani körülmények között magas BDNF- és TrkB-szint jellemző, azonban depresszió során ez jelentősen csökken. ${ }^{18}$ Ugyanakkor post mortem szövetekből származó mintákon kimutatták, hogy antidepresszáns kezelés hatására a BDNF hippocampalis expressziója és szérumszintje emelkedik. ${ }^{19}$ Fontos kiemelni, hogy a BDNF az egyes agyi régiókban ellentétes funkcióval bírhat. A ventralis tegmentalis-nucleus accumbens területen depressziószerü tüneteket eredményez, míg a hippocampusban antidepresszáns hatást közvetít. $\mathrm{Az}$ antidepresszáns hatás kialakításában és így az antidepresszánsok hatásmechanizmusában a TrkBmediált jelátviteli útvonal kulcsfontosságú ${ }^{20}$

Számos in vitro és in vivo tanulmány igazolta, hogy a gyulladás - amely a DM és a depresszió patomechanizmusában egyaránt kulcsfontosságú - hatással van a BDNF expressziójára. ${ }^{21}$ Lipopoliszacharid vagy gyulladásos citokinek bejuttatása az agyba nagymértékben csökkenti a BDNF szintjét. ${ }^{22}$

A BDNF neurotrofikus szerepe mellett egyre intenzívebben kutatják metabotrofikus hatásait is. Feltételezések szerint a BDNF számos szív-érrendszeri és metabolikus betegség patomechanizmusában is szerepet játszik. Állatkísérletek alapján, a db/db (leptinreceptor-hibás) T2DM-es egerekben a BDNF mérsékeli az inzulinrezisztenciát, csökkenti a vércukorszintet és protektív hatású a hasnyálmirigy szigetsejtjeire. ${ }^{23}$ Krabbe és munkacsoportja cukorbetegeken végzett vizsgálatai igazolták, hogy a krónikusan emelkedett vércukorszint csökkenti a BDNF felszabadulását az agyból, és a glukózmetabolizmus romlásával párhuzamosan csökken a szérum BDNF-szintje. ${ }^{24}$

\section{Lokális agyi renin-angiotenzin-aldoszteron rendszer}

$\mathrm{Az}$ angiotenzin II (Ang II) és az autonóm idegrendszer közötti kapcsolatot Bickerton és Buckley írta le először 1961-ben. ${ }^{25}$ Nem sokkal később Ganten és munkatársai egyértelműen bizonyították, hogy az agyban - részben függetlenül a perifériás rendszertől - lokálisan is működik a szisztémás klasszikus renin-angiotenzin-aldoszteron rendszer (RAAS) valamennyi elemét tartalmazó és expreszszáló agyi RAAS. ${ }^{26}$

Valójában két, egymással kommunikáló RAAS található az agyban: (1) egy endogén rendszer, amely az idegsejtekben és a szinaptikus terekben a vér-agy gáton belül helyezkedik el és (2) egy olyan rendszer, amely a circumventricularis 
szerveken és a cerebrovascularis endothelsejteken keresztül a perifériás szervekből származó Ang II hatását közvetíti. ${ }^{27}$

Az agyban a renint gliasejtek és neuronok termelik, főleg a hypothalamusban és a hypophysisben. A renin expressziója és aktivitása relatíve alacsony az agyban, és az életkorral csökken. ${ }^{28} \mathrm{Az}$ angiotenzinogént főként asztrociták, illetve kisebb mértékben gliasejtek szintetizálják. ${ }^{29}$ Az agyi RAAS-elemek közül az Ang II a fő effektor molekula, amely legnagyobb mennyiségben a hypothalamus, a hypophysis, az agykéreg, az amygdala, a cerebellum és a hippocampus régióiban termelődik. ${ }^{30}$

Az idegrendszerben az Ang II kétféleképpen is kialakulhat: egyrészt extracellulárisan, így inkább neurohormonális funkciója dominál, másrészt az idegsejtek az angiotenzinogént felvehetik és intracellulárisan alakítják át Ang II-vé, amely ebben az esetben neuro- vagy kotranszmitterként müködik. ${ }^{31}$ Az agyban az angiotenzinreceptor (AT) 1 és az AT 2 mellett AT 4 is kifejeződik, amelynek szubsztrátjai az Ang II különböző metabolitjai: az angiotenzin III, IV és az angiotenzin $1-7,{ }^{32}$ amelyek funkciója részleteiben egyelőre még nem ismert.

Az agyban kis mennyiségben termelődik aldoszteron, de emellett a vér-agy gáton átjutva is képes kifejteni hatását a nucleus tractus solitarii és a ventromedialis hypothalamusmag régiójában lévő neuronok mineralokortikoid-receptoraihoz (MR) kötődve. ${ }^{33}$

Bár a rendszer összes funkciója és szabályozása még nem tisztázott, de bizonyított, hogy az agyi RAAS kiemelkedő szerepet játszik a centrális vérnyomás kontrollálásában.

A vérnyomás-szabályozáson kívül az agyi RAAS részt vesz a hőháztartás és a lokomotoros aktivitás szabályozásában, ${ }^{34,35}$ valamint fontos a memória kialakításában, viselkedési és tanulási folyamatokban is. ${ }^{36}$ Állatkísérletek és klinikai vizsgálatok alátámasztják, hogy a lokális agyi RAAS fokozott működése szerepet játszik egyes idegrendszeri kórképek, mint pl. az Alzheimer-kór ${ }^{37}$ és a depresszió $^{38}$ patomechanizmusában.

\section{RAAS-gátlók és a depresszió kapcsolata}

A RAAS-gátlók pleiotróp antihypertensiv és nefroprotektív hatásai a közelmúltban új megvilágításba kerültek. Megfigyelték, hogy angiotenzinreceptor-blokkolót (ARB) vagy angiotenzinkonvertáló enzim (ACE)-gátlót szedő hypertoniás betegeknél csökken a depresszió és javulnak a kognitív funkciók, emellett kevesebb antidepresszánst igényeltek, mint azok a betegek, akik vérnyomáscsökkentőként $\beta$-blokkolót szedtek. ${ }^{39}$ Ezen klinikai vizsgálatok eredményei felvetették a RAAS-gátlók antidepresszáns tulajdonságát.

A RAAS-gátlók antidepresszív hatásáról DM kapcsán csupán három tanulmány készült. Pavlatou és munkatársai kimutatták, hogy normotoniás, T2DM-ben szenvedő betegekben javul a depresszió ACE-gátló kezelés hatására. ${ }^{40}$ Közel ezer T1DM-es betegen végzett vizsgálat szerint azok, akik a társuló veseszövődmények miatt RAAS-gátló kezelést kaptak, kisebb dózisú antidepresszánst (szelektív szerotoninvisszavétel-gátló [SSRI] vagy monoaminoxidáz [MAO]-gátló) igényeltek, mint akik nem részesültek RAAS-inhibitor terápiában. ${ }^{41}$

A klinikai tapasztalatokat állatkísérletes adatok is megerősítik, amelyek kimutatták, hogy ARB-k vagy ACE-gátlók antidepresszáns hatással bírnak számos depresszióteszt (erőltetett úszásteszt, tanult tehetetlenség teszt) során. ${ }^{42} \mathrm{Az}$ eddigi egyetlen diabeteses állatkísérletes eredmény szerint telmiszartánnal végzett 3 hetes kezelés antidepresszáns hatást fejtett ki T1DM korai szakaszában. ${ }^{43}$

Az aldoszteronantagonisták antidepresszáns hatásával kapcsolatos kutatások nem ennyire egységesek. Míg az állatkísérletek azt bizonyítják, hogy szisztémásan vagy közvetlenül az agyba juttatott spironolakton antidepresszáns hatású, ${ }^{44}$ addig humán tanulmányokban az MR antagonizálása felfüggesztette a triciklusos antidepresszánsok által jelentkező javulást. ${ }^{45}$

A RAAS-gátlók antidepresszáns hatásának hátterében a szerek neuroprotektív tulajdonságát feltételezik. Mivel a vérnyomás normalizálása neuroprotekciót eredményez hypertoniás betegekben, ezért eleinte úgy gondolták, hogy a RAAS-gátlók jótékony hatása összefügg a szerek vérnyomáscsökkentő szerepével. Azonban a közelmúltban igazolódott, hogy a RAAS-gátlók neuroprotektív hatása független vérnyomáscsökkentő tulajdonságuktól. Stroke experimentális modelljében kimutatták, hogy az ARB kandeszartán erősebb neuroprotektív hatással rendelkezik, mint a $\beta$-blokkoló propanolol vagy a kalciumcsatorna-blokkoló amlodipin. ${ }^{46}$ 


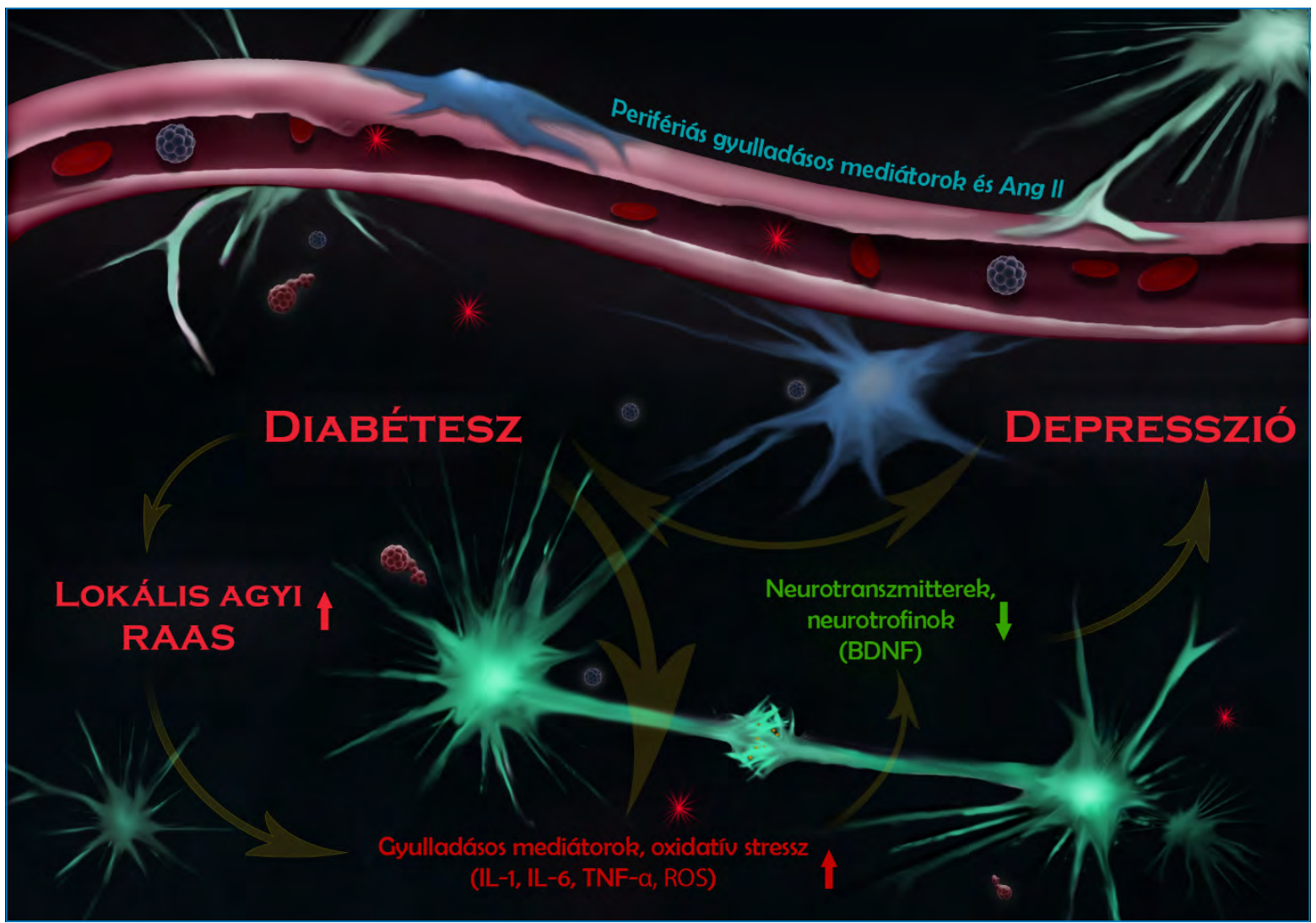

\section{1. ábra. A diabetes és a depresszió kapcsolata.}

Diabetes során az emelkedett vércukorszint, valamint az esetleges obezitás hatására egyes gyulladásos citokinek szisztémás szintje megnő. A központi idegrendszerbe bejutott proinflammatorikus mediátorok gyulladásos folyamatokat indukálnak, az oxidatív stressz hatására pedig megnő a reaktív oxigénvegyületek (ROS) mennyisége. Ennek következtében csökken a monoaminok és neurotrofinok, többek között az agyi neurotrofikus faktor (BDNF) szintje, ami depressziószerü tüneteket idéz elö. A depresszió kapcsán létrejövő szubklinikus gyulladás hozzájárul a béta-sejtek csökkent müködéséhez és ezáltal az inzulinrezisztencia, illetve a 2-es típusú diabetes létrejöttéhez. Továbbá bizonyított, hogy a renin-angiotenzin-aldoszteron rendszer (RAAS)-gátlók hatására javulnak a depressziós tünetek és a kognitív funkciók, ami igazolja a lokális agyi RAAS szerepét a neuroprotekció kialakulásában és a depreszszió patomechanizmusában

Feltételezik, hogy a RAAS-inhibitorok antidepresszáns hatásának hátterében főként az agyi RAAS múködésének gátlása állhat. Az agyban az Ang II elsődlegesen stresszhormonként funkcionál, lokálisan is termelődik, illetve a vér-agy gáton átjutva a szisztémás keringésből is bekerülhet a központi idegrendszerbe. ${ }^{47} \mathrm{Az}$ Ang II szintje az akut vagy krónikus stresszhatásra - mint ahogyan a diabeteses állapot is - megemelkedik, és gyulladásos folyamatokat, valamint a hypothalamus-hypophysis-mellékvese tengely aktivációját idézi elő, ami depressziószerű viselkedést eredményezhet. ${ }^{48}$ A gyulladás csökkenti a neurotrofinok - köztük a BDNF - expresszióját, ami ugyancsak hozzájárul a kognitív funkciózavarhoz és depresszió kialakulásához. ACE-inhibitorokról (captopril, perindopril) és ARB-ről (telmiszartán) egyaránt igazolták, hogy az agyban is mérsékelik a gyulladást a mikrogliaaktiváció és a gyulladásos markerek szintjének csökkentése révén. ${ }^{49}$

A cukorbetegség napjaink egyik legjelentősebb népegészségügyi problémája, amely hatalmas 
egészségügyi és gazdasági terhet jelent az euroatlanti társadalmak számára. A depresszió szintén milliókat érintő népbetegség világszerte. A cukorbetegek több mint $40 \%$-a depressziós tünetekkel küzd, ami rontja a metabolikus kontrollt és a betegek terápiahűségét, valamint növeli a DM indukálta szövődmények kialakulását és a mortalitást. ${ }^{50}$ A depresszió gyakori előfordulásának ellenére a DM-hez társuló hangulatzavarok sokszor nem kerülnek felismerésre, és a betegek nem részesülnek megfelelő terápiában. A kezelés eredményességét tovább nehezíti, hogy a DM és a depresszió közötti pontos patofiziológiai kapcsolat mindmáig nem tisztázott, azonban a RAAS szerepe igazolt mindkét betegség patomechanizmusában (1. ábra). Mindezen klinikai megfigyelések és állatkísérletes adatok azonban felvetik, hogy a RAAS gátlása a hypertonia és a vesekárosodás mérséklése mellett jótékony hatású lehet a cukorbetegséghez társuló depresszió megelőzésében is.

Közlésre érkezett: 2019. március 25.

Közlésre elfogadva: 2019. május 16.

\section{A levelezésért felelős szerző címe: \\ Dr. Lénárt Lilla}

SE. I. sz. Gyermekgyógyászati Klinika 1083 Budapest, Bókay János utca 54. E-mail: lenart.lillaa@gmail.com
Irodalom

1. Willis T: Diabetes: A medical odyssey. Tuckahoe, NY, USV Pharmaceutical Corp, 1971.

2. Nouwen A, Lloyd CE, Pouwer F: Depression and type 2 diabetes over the lifespan: a meta-analysis. Response to Mezuk et al. Diabetes Care 2009; 32(5): e56; author reply e7. doi:10.2337/dc09-0027

3. Anderson RJ, Freedland KE, Clouse RE, Lustman PJ: The prevalence of comorbid depression in adults with diabetes: a meta-analysis. Diabetes Care 2001; 24(6): 1069-1078. doi:10.2337/diacare.24.6.1069

4. de Groot M, Anderson R, Freedland KE, Clouse RE, Lustman PJ: Association of depression and diabetes complications: a meta-analysis. Psychosom Med 2001; 63(4): 619-630.

5. Payne ME, Steck SE, George RR, Steffens DC: Fruit, vegetable, and antioxidant intakes are lower in older adults with depression. J Acad Nutr Diet 2012; 112(12): 2022-2027. doi:10.1016/j.jand.2012.08.026

6. Korczak DJ, Pereira S, Koulajian K, Matejcek A, Giacca A: Type 1 diabetes mellitus and major depressive disorder: evidence for a biological link. Diabetologia 2011; 54(10): 2483-2493. do: 10.1007/s00125-011-2240-3

7. Foss-Freitas MC, Foss NT, Rassi DM, Donadi EA, Foss MC: Evaluation of cytokine production from peripheral blood mononuclear cells of type 1 diabetic patients. Ann N Y Acad Sci 2008; 1150: 290-296. doi:10.1196/annals.1447.053

8. Li J, Huang M, Shen X: The association of oxidative stress and proinflammatory cytokines in diabetic patients with hyperglycemic crisis. I Diabetes Complications 2014; 28(5): 662-666. doi:10.1016/j.jdiacomp.2014.06.008

9. Maury E, Brichard SM: Adipokine dysregulation, adipose tissue inflammation and metabolic syndrome. Mol Cell Endocrinol 2010; 314(1): 1-16. doi:10.1016/j.mce.2009.07.031

10. Felger JC, Lotrich FE: Inflammatory cytokines in depression: neurobiological mechanisms and therapeutic implications. Neuroscience 2013; 246: 199-229. doi:10.1016/j.neuroscience.2013.04.060

11. Raison CL, Capuron L, Miller AH: Cytokines sing the blues: inflammation and the pathogenesis of depression. Trends Immunol 2006; 27(1): 24-31. doi:10.1016/j.it.2005.11.006

12. Dantzer R, O'Connor JC, Freund GG, Johnson RW, Kelley KW: From inflammation to sickness and depression: when the immune system subjugates the brain. Nat Rev Neurosci 2008; 9(1): 46-56. doi:10.1038/nrn2297

13. McIntyre RS, Soczynska JK, Konarski JZ, Woldeyohannes HO, Law CW, Miranda A, et al: Should Depressive Syndromes Be Reclassified as "Metabolic Syndrome Type II"? Ann Clin Psychiatry 2007; 19(4): 257-264. doi:10.1080/10401230701653377

14. Lu B, Pang PT, Woo NH: The yin and yang of neurotrophin action. Nat Rev Neurosci 2005; 6(8): 603-614. doi:10.1038/nnn1726

15. Cunha C, Brambilla R, Thomas KL: A simple role for BDNF in learning and memory? Front Mol Neurosci 2010; 3: 1. doi:10.3389/neuro.02.001.2010

16. Lee R, Kermani P, Teng KK, Hempstead BL: Regulation of cell survival by secreted proneurotrophins. Science 2001; 294(5548): 1945-1948. doi:10.1126/science. 1065057

17. Autry AE, Monteggia LM: Brain-derived neurotrophic factor and neuropsychiatric disorders. Pharmacol Rev 2012; 64(2): 238-258. doi:10.1124/pr. 111.005108

18. Castren E, Voikar V, Rantamaki T: Role of neurotrophic factors in depression. Curr Opin Pharmacol 2007; 7(1): 18-21. doi:10.1016/j.coph.2006.08.009 
19. Shimizu E, Hashimoto K, Okamura N, Koike K, Komatsu N, Kumakiri C, et al: Alterations of serum levels of brain-derived neurotrophic factor (BDNF) in depressed patients with or without antidepressants. Biol Psychiatry 2003; 54(1): 70-75. doi:10.1016/50006-3223(03)00181-1

20. Coyle JT, Duman RS: Finding the intracellular signaling pathways affected by mood disorder treatments. Neuron 2003; 38(2): 157-160. doi:10.1016/50896-6273(03)00195-8

21. Calabrese F, Rossetti AC, Racagni G, Gass P, Riva MA, Molteni R: Brain-derived neurotrophic factor: a bridge between inflammation and neuroplasticity. Front Cell Neurosci 2014; 8: 430. doi:10.3389/fncel.2014.00430

22. Guan Z, Fang J: Peripheral immune activation by lipopolysaccharide decreases neurotrophins in the cortex and hippocampus in rats. Brain Behav Immun 2006; 20(1): 64-71. doi:10.1016/j.bbi.2005.04.005

23. Yamanaka M, Itakura Y, Ono-Kishino M, Tsuchida A, Nakagawa T, Taiji $\mathrm{M}$ : Intermittent administration of brain-derived neurotrophic factor (BDNF) ameliorates glucose metabolism and prevents pancreatic exhaustion in diabetic mice. J Biosci Bioeng 2008; 105(4): 395-402. doi:10.1263/jbb.105.395

24. Krabbe KS, Nielsen AR, Krogh-Madsen R, Plomgaard P, Rasmussen P, Erikstrup C, et al.: Brain-derived neurotrophic factor (BDNF) and type 2 diabetes. Diabetologia 2007; 50(2): 431-438. doi:10.1007/s00125-006-0537-4

25. Bickerton RK, Buckley JP: Evidence for a central mechanism of angiotensin induced hypertension. Proceedings of the Society for Experimental Biology and Medicine 1961; 106: 834-847. doi:10.3181/00379727-106-26492

26. Sakai K, Sigmund CD: Molecular evidence of tissue renin-angiotensin systems: a focus on the brain. Curr Hypertens Rep 2005; 7(2): 135-140. doi:10.1007/s11906-005-0088-y

27. Paul M, Poyan Mehr A, Kreutz R: Physiology of local renin-angiotensin systems. Physiol Rev 2006; 86(3): 747-803. doi:10.1152/physrev.00036.2005

28. Iwai N, Inagami T: Quantitative analysis of renin gene expression in extrarenal tissues by polymerase chain reaction method. J Hypertens 1992; 10(8): 717-724. doi:10.1097/00004872-199208000-00004

29. Bunnemann B, Fuxe K, Metzger R, Bjelke B, Ganten D: The semiquantitative distribution and cellular localization of angiotensinogen mRNA in the rat brain. I Chem Neuroanat 1992; 5(3): 245-262. doi:10.1016/0891-0618(92)90049-V

30. Phillips MI, Stenstrom B: Angiotensin II in rat brain comigrates with authentic angiotensin II in high pressure liquid chromatography. Circ Res 1985; 56(2): 212-219. doi:10.1161/01.RES.56.2.212

31. Paul M, Bader M, Steckelings UM, Voigtlander T, Ganten D: The reninangiotensin system in the brain. Localization and functional significance. Arzneimittelforschung 1993; 43(2A): 207-213.

32. Mckinley MJ, Albiston AL, Allen AM, Mathai ML, May CN, McAllen RM, et al.: The brain renin-angiotensin system: location and physiological roles. Int J Biochem Cell Biol 2003; 35(6): 901-918. doi:10.1016/S1357-2725(02)00306-0

33. Roland BL, Li KX, Funder JW: Hybridization histochemical localization of 11 beta-hydroxysteroid dehydrogenase type 2 in rat brain. Endocrinology 1995; 136(10): 4697-4700. doi:10.1210/endo.136.10.7664691

34. Watanabe T, Hashimoto M, Okuyama S, Inagami T, Nakamura S: Effects of targeted disruption of the mouse angiotensin II type 2 receptor gene on stress-induced hyperthermia. J Physiol 1999; 515(Pt 3): 881-885. doi:10.1111/j.1469-7793.1999.881ab.x

35. Belcheva I, Chobanova M, Georgiev V: Differential behavioral effects of angiotensin II microinjected unilaterally into the CAI hippocampal area. Regul Pept 1998; 74(2-3): 67-71. doi:10.1016/50167-0115(98)00015-9
36. Braszko JJ, Walesiuk A, Wielgat P: Cognitive effects attributed to angiotensin II may result from its conversion to angiotensin IV. J Renin Angiotensin Aldosterone Syst 2006; 7(3): 168-174. doi:10.3317/jraas.2006.027

37. Wang J, Ho L, Chen L, Zhao Z, Zhao W, Qian X, et al.: Valsartan lowers brain beta-amyloid protein levels and improves spatial learning in a mouse model of Alzheimer disease. I Clin Invest 2007; 117(11): 3393-3402. doi:10.1172/JC131547

38. Isingrini E, Desmidt T, Belzung C, Camus V: Endothelial dysfunction: A potential therapeutic target for geriatric depression and brain amyloid deposition in Alzheimer's disease? Curr Opin Investig Drugs 2009; 10(1): 46-55.

39. Braszko JJ, Karwowska-Polecka W, Halicka D, Gard PR: Captopril and enalapril improve cognition and depressed mood in hypertensive patients. J Basic Clin Physiol Pharmacol 2003; 14(4): 323-343. doi:10.1515/JBCPP.2003.14.4.323

40. Pavlatou MG, Mastorakos G, Lekakis I, Liatis S, Vamvakou G, Zoumakis E, et al.: Chronic administration of an angiotensin II receptor antagonist resets the hypothalamic-pituitary-adrenal (HPA) axis and improves the affect of patients with diabetes mellitus type 2: preliminary results. Stress 2008; 11(1): 62-72. doi:10.1080/10253890701476621

41. Ahola AJ, Harjutsalo V, Forsblom C, Groop PH: Renin-angiotensinaldosterone-blockade is associated with decreased use of antidepressant therapy in patients with type 1 diabetes and diabetic nephropathy. Acta Diabetol 2014; 51(4): 529-533. doi:10.1007/s00592-013-0547-x

42. Nayak V, Patil PA: Antidepressant activity of fosinopril, ramipril and losartan, but not of lisinopril in depressive paradigms of albino rats and mice. Indian J Exp Biol 2008; 46(3): 180-184.

43. Aswar U, Chepurwar S, Shintre S, Aswar M: Telmisartan attenuates diabetes induced depression in rats. Pharmacol Rep 2017; 69(2): 358-364. doi:10.1016/j.pharep.2016.12.004

44. Wu TC, Chen HT, Chang HY, Yang CY, Hsiao MC, Cheng ML, et al:: Mineralocorticoid receptor antagonist spironolactone prevents chronic corticosterone induced depression-like behavior. Psychoneuroendocrinology 2013; 38(6): 871-883. doi:10.1016/j.psyneuen.2012.09.011

45. Holsboer F: Stress, hypercortisolism and corticosteroid receptors in depression: implications for therapy. J Affect Disord 2001; 62(1-2): 77-91. doi:10.1016/50165-0327(00)00352-9

46. Nishimura Y, Ito T, Saavedra JM: Angiotensin II AT(1) blockade normalizes cerebrovascular autoregulation and reduces cerebral ischemia in spontaneously hypertensive rats. Stroke 2000; 31(10): 2478-2486. doi:10.1161/01.STR.31.10.2478

47. Saavedra JM, Ando H, Armando I, Baiardi G, Bregonzio C, Jezova M, et al.: Brain angiotensin II, an important stress hormone: regulatory sites and therapeutic opportunities. Ann N Y Acad Sci 2004; 1018: 76-84. doi:10.1196/annals.1296.009

48. Saavedra JM: Angiotensin II AT(1) receptor blockers as treatments for inflammatory brain disorders. Clin Sci (Lond) 2012; 123(10): 567-590. doi:10.1042/CS20120078

49. Torika N, Asraf K, Roasso E, Danon A, Fleisher-Berkovich S: Angiotensin converting enzyme inhibitors ameliorate brain inflammation associated with microglial activation: possible implications for Alzheimer's disease. J Neuroimmune Pharmacol 2016; 11(4): 774-785. doi:10.1007/s11481-016-9703-8

50. Egede LE, Ellis C: Diabetes and depression: global perspectives. Diabetes Res Clin Pract 2010; 87 (3): 302-312. doi:10.1016/j.diabres.2010.01.024 